\title{
The Impact of Share Repurchase on the Value of Listed Companies Take Alibaba Group as an Example
}

\author{
Mingzhu Yang ${ }^{1}$ \\ ${ }^{1}$ Henan University, Henan, China
}

\begin{abstract}
Share repurchase is a common dividend policy and financial policy in western listed companies. The share repurchase policy has some positive and negative effects on the company. Therefore, this paper takes Alibaba Group as an example, and studies its share repurchase policy from 2014 after its listing to 2019. A theoretical and empirical analysis on the profitability, market value and stock price of listed companies through share repurchase is conducted. The result shows that it has positive effects on corporate profitability, market value and capital structure. At last, suggestions based on the analysis are proposes.
\end{abstract}

\section{ITRODUCTION}

In recent years, as a dividend policy and financial policy, share repurchase is more and more popular with listed companies. This paper will take Alibaba Group as an example to study and analyze the impact of the share repurchase policy on the company's value from the aspects of profitability, market value, stock price and capital structure, and suggest that it should treat the repurchased common shares as treasury shares instead of writing them off, and not carry out long-term share repurchase activities to avoid the lack of liquidity.

\section{SHARE REPURCHASE}

\subsection{The Concept of Stock Repurchase}

Stock repurchase is a behaviour of using the company's debts or retained earnings financing of listed companies to buy the company's outstanding common stock at a certain price [1]. There are two ways to handle repurchased stock: one is to cancel the stock repurchase, and another is to make the repurchased stock as a treasury stock to reserve, which still belongs to the outstanding shares, while the company does not participate in the calculation of earnings per share and income distribution. The second is the main way in which a company's share capital is reduced.

\subsection{The Role of Share Repurchase}

\subsubsection{As the Dividend Policy of Company}

When a company has a lot of cash but no reinvestment or merger or acquisition opportunities, it can distribute the cash to shareholders, either through cash dividends or share repurchase. In particular, if the company pays cash to shareholders in the form of share repurchase, the shareholders are exempt from personal income tax.

\subsubsection{Improve Profitability and Market Value of Company}

From the perspective of financial leverage, according to the revised MM capital structure theory, the right amount of debt will help the company to play its role as financial leverage more effectively. Moreover, using debt to achieve share repurchase can also play the role of tax shield, reduce tax expenditures, so as to enhance the company's profitability and increase the market value of the company [2].

From the perspective of net earnings per share, compared with the cash dividend, share repurchase can reduce the number of common shares outstanding. Since the repurchase shares are not involved in the calculation of net earnings per share, it increases the net earnings per share.

From the perspective of corporate governance, share repurchase is used to transfer cash flow to shareholders, thus avoiding management 's use of the company 's residual cash flow for inefficient investments, mergers, acquisitions, etc., thereby reducing agency risk and improving the company's profitability and market value indirectly.

\subsubsection{Passing on Company Information}

The information between the company's management and 
shareholders is asymmetric. When the company believes that the stock price is undervalued by the market, it can use the method of stock repurchase to tell the shareholders and investors that the stock price of the company is undervalued, thus improving the stock price of company.

\subsubsection{Anti-takeover strategy}

After the share repurchase, the share price of the company will rise, and the number of shares outstanding will decreases. Therefore, the shareholding ratio of the original shareholders of the company will increase, leading to the enhancement of the control power. As a result, the acquisition difficulty will increase naturally, so that the purpose of anti-acquisition will be achieved.

\section{THE IMPACT OF SHARE REPURCHASE OF ALIBABA GROUP}

\subsection{The Share Repurchase Incident of Alibaba Group}

In August 2015, the board of directors of Alibaba Group approved a share repurchase program of up to four billion dollars over the next two years. On Feb. 29, 2016, Mr. Ma and Mr. Zhou said Alibaba Group would pay five hundred million dollars for Yahoo shares as part of a four billion dollars repurchase program announced in August 2015. As a result of, Yahoo's stock has been rising, even rising 3.2 percent on March $2^{\text {nd }}$. And it soared to 32.80 dollars in 2016, reaching a new level [3].

In May 2017, the board of directors of Alibaba Group authorized a two-year, six billion dollars share repurchase program, and in September 2018 announced the ADS repurchase program to implement the previously announced six billion dollars share repurchase program. As of November 1st, 2018, Alibaba Group had repurchased 9.12 million shares for 1.33 billion dollars. By the end of March 2019, the company had bought back about 10.9 million ADS, or about 1.57 billion dollars [4].

\subsection{Earnings Per Share of Alibaba Group}

First of all, the value of a company can be measured by its earnings per share. From the following data, Alibaba Group share repurchase is inevitable. As can be seen from fig. 1, when Alibaba Group was listed on the New York stock exchange on September 19th, 2014, its stock price was not high, and even fell below the issue price in 2015 . As a result, in August 2015, Alibaba Group announced a four billion dollars two-year share repurchase program to offset the diluted impact of an equity award program. At the same time, Mr. Ma and Mr. Zhou added five billion dollars to their private holdings. The calculation formula of earnings per share can be used here to explain the decision.

earnings per share $=$ net profit of common stock/ number of common stock shares outstanding (1)

From the formula (1), it can be seen, if the total capital stock changes, the earnings per share will also change in the opposite direction. And the total capital stock decreases, then earnings per share increases. As shown in fig. 2, the earnings per share increased from 10.33 in 2015 to 29.07 in 2016 , which has an increase of $181.41 \%$. As shown in fig. 1, although the increase of stock price from 2015 to 2016 is not obvious, the earnings per share does have a very high growth rate, indicating that the share repurchase has a positive effect.

After that, on Feb. 29, 2016, Mr. Ma and Mr. Zhou said Alibaba Group would pay five billion dollars for Yahoo shares as part of a four billion dollars repurchase program announced in August 2015 [3]. This repurchase is not only about boosting Alibaba's share price but also about strengthening control. Even though Alibaba Group bought back half of its shares for six billion dollars in 2012, Yahoo still owns a one-fifth stake since Yahoo bought a $40 \%$ stake in Alibaba Group in 2005 [3]. With the decline of Yahoo's search business, it is repurchase that not only sent a signal to the market that the share price was undervalued, which make the share price rises later, but also strengthen Alibaba's control, which has the effect of killing two birds with one stone.

In May 2017, Alibaba Group announced a two-year six billion dollars share repurchase program, followed by an ADS repurchase program in September 2018. By the end of March 2019, the company had bought back about 10.9 million ADS, or about 1.57 billion dollars. As can be seen from fig. 2, the earnings per share in 2018 is 25.06, which has an increase of $43.04 \%$ from 17.52 in 2017, and the earnings per share in 2019 is 33.95 , which has an increase of $35.47 \%$ from 2018 . Besides, it can be seen from figure 1 that the stock price has been soaring since 2017 .

However, the earnings per share only represent the earnings per share in a certain year but the continuity, it is impossible to measure the change of the company's growth alone. Thus, the return on assets and asset-liability ratio are used as supplements.

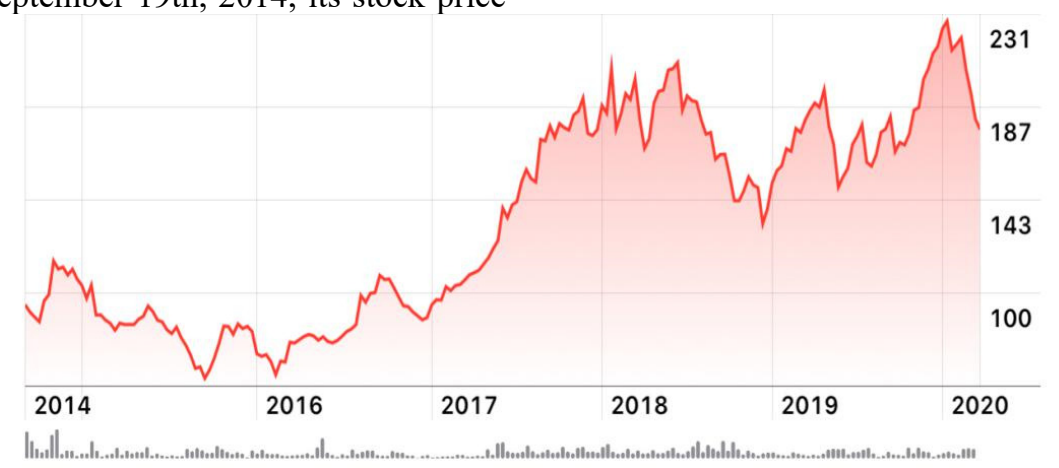

Fig1. The price of the stock of Alibaba Group 


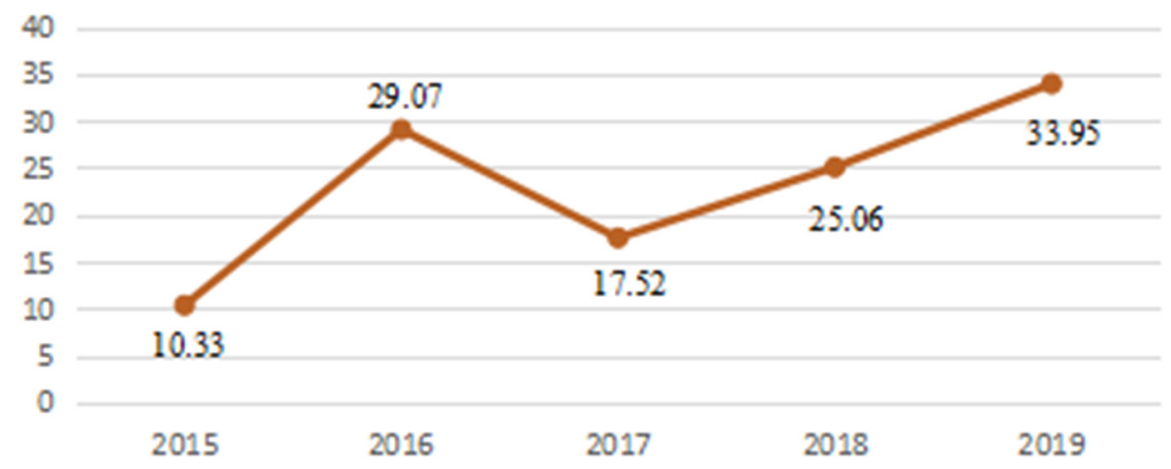

Fig2. Earnings per share of Alibaba Group

Source: with the exception of figure 1, all other figures are for Alibaba's fiscal year, that is, the end of the year is March 31th of each year. And all the data in the figures are calculated by Alibaba's financial statements

\subsection{Return on Assets of Alibaba Group}

The rate of return on assets(ROA) measures the profit brought by each dollar of assets [5]. It is used to evaluate the overall profitability of an enterprise by using all the assets, and is an important indicator to evaluate an enterprise. Therefore, this paper selects return on assets as an index to measure Alibaba's profitability.
As shown in fig. 3, the four billion dollar repurchase program in August 2015 brought the return on assets to $19.57 \%$ in 2016 , which has an increase of $105.57 \%$ from the return on assets in 2015. Then a six billion dollars repurchase program in May 2017 resulted in a return on assets growth rate of 5.29 percent in 2018. Although the growth rate in 2019 is $-2.92 \%$, the return on assets is still higher than that in 2017. In addition, the total assets in 2019 increased by $90.42 \%$ compared with 2017 , and the after-tax profit increased by $94.62 \%$ compared with 2017 . Thus, repurchase has a positive effect on the company's profitability.

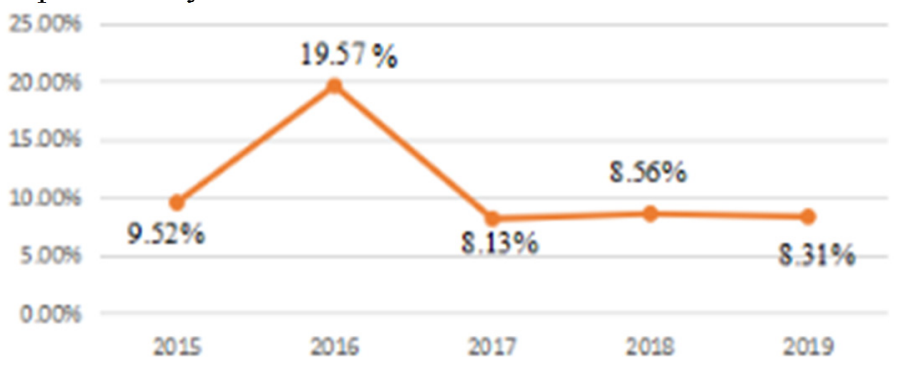

Fig3. Return on assets of Alibaba Group

Table1. ASSET STRUCTURE OF ALIBABA GROUP FROM 2015 TO 2019

\begin{tabular}{|c|c|c|c|c|c|}
\hline & 2015 & 2016 & 2017 & 2018 & 2019 \\
\hline EBIT & 24.32 & 71.289 & 41.226 & 61.412 & 80.234 \\
\hline Total Assets & 255.434 & 364.245 & 506.812 & 717.124 & 965.076 \\
\hline Total Liabilities & 97.363 & 114.356 & 182.691 & 277.685 & 349.674 \\
\hline Shareholders' Equity & 158.071 & 249.889 & 324.121 & 439.439 & 615.402 \\
\hline
\end{tabular}

\subsection{Asset-liability Ratio of Alibaba Group}

Finally, the asset-liability ratio can be used to measure Alibaba's capital structure. Since issuing shares is an act to raise funds, which can be regarded as a kind of liability, while share repurchase is an act to reduce liabilities. Thus, as shown in figure 4 , the asset-liability ratio decreased by $17.63 \%$ in 2016 . The increase in the asset-liability ratio from 2016 to 2018 is mainly due to the company's merger and acquisition activities. For example, in 2016, Alibaba
Group acquired a controlling stake in Lazada, a leading ecommerce platform in southeast Asia, and then wholly acquired Daraz in 2018. However, from fig. 4 and the data in [4], it can be concluded that from May 2017, when the announcement of a six billion dollars repurchase plan was made, to the end of March 2019, Alibaba Group has repurchased about 10.9 million ADS shares, a total of about 1.57 billion dollars, which has also had some impact on the company's capital structure with the asset-liability ratio has been reduced from $38.72 \%$ in 2018 to $36.23 \%$ in 2019. 


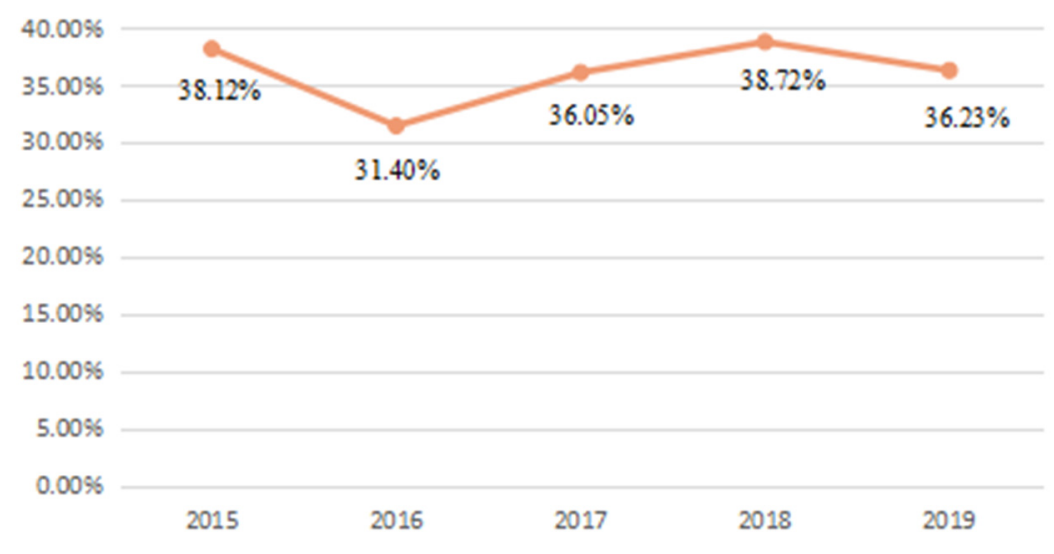

Fig4. Asset-liability ratio of Alibaba Group

\section{POTENTIAL PROBLEMES AND SUGGESTIONS}

\subsection{The Cancel of Repurchased Shares}

After completing the repurchase, Alibaba Group mostly cancels the repurchased shares, but it is better to keep them as treasury shares. There are two reasons that can explain this argument.

Firstly, when necessary treasury shares can be distributed as an employee welfare payments to employees, especially senior management. If the senior managers hold a certain number of stocks, they will stand on the side of shareholders when making decisions in investment. Moreover, they are likely to seek stable development of the company spontaneously. That can reduce the agency risk effectively as well.

Secondly, Alibaba Group has carried out many merger and acquisition policies from 2014 to 2019. For example, Alibaba raised its shareholding in Lazada Group from 51\% to about $83 \%$ in June 2017 , fully acquired Daraz in 2018, then acquired Chinese import e-commerce platform Koala in 2019. In addition, it increased its shareholding in Cainiao network to about 63\% [4]. If Alibaba Group has treasury stock, it can swap them for equity, when acquiring the company. These measures can reduce the company's cash expenditure.

\subsection{A Long-term Share Repurchase Policy}

Judging from Alibaba's share repurchase, the company has had a continuing share repurchase program since listing on the New York stock exchange. However, the stock repurchase requires a large amount of capital to cover the cost of repurchase, easily leading to capital shortage and asset liquidity deterioration, thus affecting the long-term development of the company. The current ratio in fig. 5 shows a downward trend, suggesting that the short-term solvency of the company is reduced and the liquidity of assets becomes worse, so that the risk is also increased.

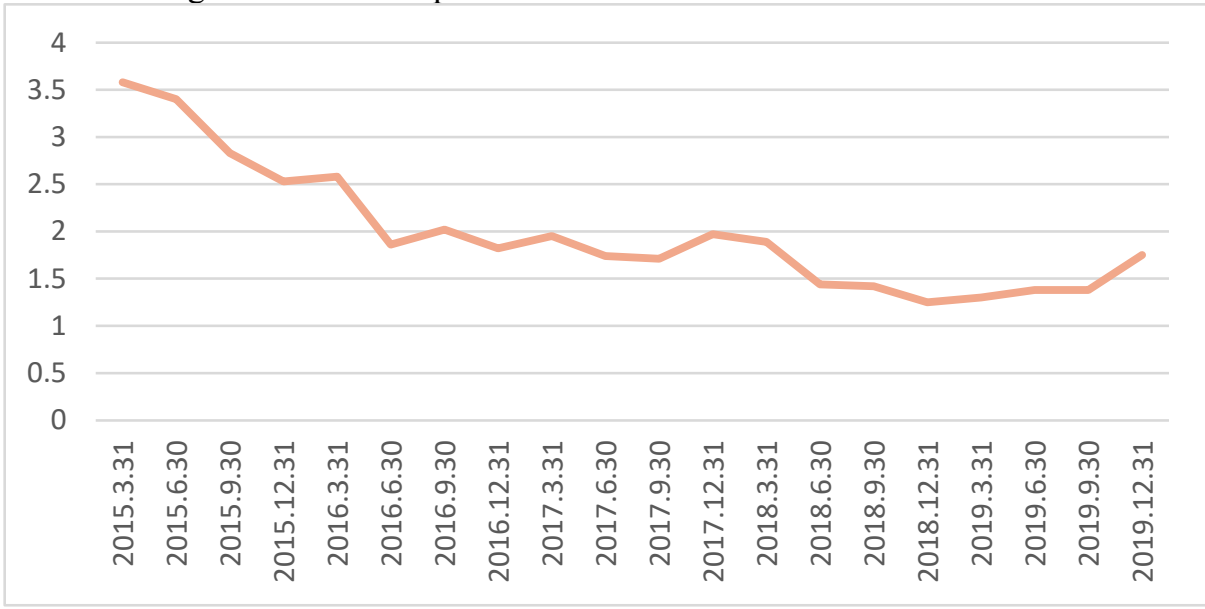

Fig5. Current ratio of Alibaba Group

\section{CONCLUSION}

As a dividend policy and financial policy, the share repurchase plays a positive role in improving the company's profitability and market value. Besides, it can also improve the company's capital structure and raises the company's share price. In addition, the share repurchase can send a signal to the market that the company's share price is undervalued, strengthen corporate control and enhance investor confidence. However, it will also reduce the liquidity of the company's assets and affect the company's long-term development. At present, the research of this paper still has some shortcomings, such as the single object of research and analysis. And the influence of other business activities of the company is not excluded. Therefore, the author will integrate other listed companies of the stock repurchase plan for horizontal research in the future. 


\section{ACKNOWLEDGMENT}

First and foremost, I would like to show my deepest gratitude to my teachers and professors in my university, who have provided me with valuable guidance in every stage of the writing of this thesis. Further, I would like to thank all my friends and roommates for their encouragement and support. Without all their enlightening instruction and impressive kindness, I could not have completed my thesis.

\section{REFERENCES}

1. G. Xu, M. Chi. Share Repurchase and Corporation Value--Theoretical and Empirical Analysis. Management science, 2003, vol. 016, no. 004, pp. 6064.

2. D. Liu, J. Zhang, R. Qi, et al. Analysis of the factors influencing the reaction of share repurchase market - empirical evidence from China's A-share market. Journal of $\mathrm{Xi}$ 'an jiaotong university (Social science edition), 2009, vol. 05, pp. 29-33.

3. Starling. Alibaba's industry layout. Business culture, 2016, No.319(10), pp. 1-8.

4. Data from: www.alibabagroup.com. Accessed on March 27, 2020.

5. S. A. Ross, R. W. Westerfield, J. Jaffe. Rate on assets is a measure of profit per dollar of assets. Corporate Finance. 2010, pp.110. 